\title{
Bacterial Leaf Spot of Celery in California: Etiology, Epidemiology, and Role of Contaminated Seed
}

\author{
E. L. Little, Department of Plant Pathology, University of California, Davis 95616; S. T. Koike, University of Cali- \\ fornia Cooperative Extension, Salinas 93901; and R. L. Gilbertson, Department of Plant Pathology, University of \\ California, Davis 95616
}

\begin{abstract}
Little, E. L., Koike, S. T., and Gilbertson, R. L. 1997. Bacterial leaf spot of celery in California: Etiology, epidemiology, and role of contaminated seed. Plant Dis. 81:892-896.

Pseudomonas syringae pv. apii, causal agent of bacterial leaf spot (BLS) of celery, was first identified in California in 1989. By 1991, BLS was apparent in all celery-growing areas of the state. Greenhouse-produced transplants were affected most severely, and disease incidence approached $100 \%$ in some greenhouses. In this study, sources of inoculum and factors contributing to disease development were investigated in three Salinas Valley greenhouse operations during the 1991, 1992, and 1993 celery transplant seasons (January to August). Epiphytic $P$. syringae pv. apii was not detected on celery transplants until April or May of each year. Increased epiphytic populations preceded BLS outbreaks, and high-pressure, overhead irrigation favored bacterial infiltration and disease development. In seed-wash assays, $P$. syringae pv. apii was recovered from 5 of 24 commercial celery seed lots. In field tests, epiphytic $P$. syringae pv. apii was found on umbels of inoculated celery plants, and seeds from these plants were heavily contaminated with $P$. syringae pv. apii. Contaminated seed produced seedlings with large epiphytic $P$. syringae pv. apii populations. Hot-water treatment $\left(50^{\circ} \mathrm{C}\right.$ for $\left.25 \mathrm{~min}\right)$ eliminated $>99.9 \%$ of seed contamination. Based on these results, disease management techniques are proposed.
\end{abstract}

Celery (Apium graveolens L. var. dulce (Mill.) Pers.) production in California is concentrated in cool coastal counties, such as Monterey, San Benito, Santa Barbara, and Ventura. Commercial celery fields usually are established with greenhouse-produced transplants. Transplants are grown in plug trays for 8 to 10 weeks before planting in the field. Prior to 1989 , celery-transplant growers in California had few significant disease problems, except for occasional outbreaks of late blight, caused by Septoria apiicola. In 1989, a new foliar blight was reported from a few transplant greenhouses and production fields (10). Symptoms were confined to leaves and appeared as small (2 to $5 \mathrm{~mm}$ ), angular, water-soaked lesions. Lesions later became necrotic and often coalesced and produced extensive leaf tissue death. By 1991, the disease was found in all celery-growing regions of California but was most severe on greenhouse-produced transplants $(11,17,18)$. The disease reduced the vigor and value of transplants, which occasionally resulted in the rejection of entire lots of transplants.

Following Koch's postulates, the disease was determined to be bacterial leaf spot

Corresponding author: R. L. Gilbertson

E-mail: rlgilbertson@ucdavis.edu

Accepted for publication 22 April 1997.

Publication no. D-1997-0609-01R

(C) 1997 The American Phytopathological Society
(BLS), caused by Pseudomonas syringae pv. apii $(10,11)$. P. syringae pv. apii was first described in 1921 as the causal agent of a foliar disease of celery in New York State (8). BLS, previously called northern bacterial blight (24), has since been a problem for celery producers in Midwestern and Eastern growing regions of the United States. Most losses have been due to increased trimming costs at harvest (24). A similar celery disease in Florida, referred to as bacterial blight, is incited by $P$. cichorii (26, 27).

This study evaluated several aspects of BLS associated with celery transplants to derive plausible management techniques. Once the causal agent of the disease was confirmed and reliable methods for pathogen isolation and identification were developed, additional studies were designed to relate epiphytic bacterial populations to BLS development, determine inoculum sources, and evaluate cultural practices favoring disease development.

\section{MATERIALS AND METHODS}

Identification of the causal agent of BLS disease of celery in California. Diseased celery leaves were collected from coastal celery-production fields and transplant houses. Leaf tissues excised from lesion margins were surface-disinfested in $0.5 \%$ $\mathrm{NaOCl}$ (10\% household bleach) solution for $1 \mathrm{~min}$, rinsed in sterile water, and macerated in $0.5 \mathrm{ml}$ of sterile water. Liquid from the macerate was streaked onto either King's medium B (KB) (9) or nutrient agar
(Difco Laboratories, Detroit) and incubated for 3 days at $28^{\circ} \mathrm{C}$. Colonies (73) representative of different bacteria recovered from each sample were subcultured, and singlecolony isolates were obtained. Fluorescent pseudomonads were evaluated for LOPAT (15) characteristics, including hypersensitive reaction in tobacco (Nicotiana tabacum cv. Havana 425) leaves. The pathogenicity of the bacteria was determined from inoculations on the three youngest, fully expanded leaves of 10- to 12-week-old celery plants. Bacteria from nutrient broth culture grown overnight on an orbital shaker $\left(250 \mathrm{~min}^{-1}\right)$ to $\sim 10^{9} \mathrm{CFU}$ per $\mathrm{ml}$ were swab-inoculated onto each leaf. Carborundum (320 grit) was added $(1 \mathrm{~g} / 100 \mathrm{ml})$ to broth cultures prior to inoculation. Negative controls were mock-inoculated with nutrient broth plus Carborundum, and positive controls were inoculated with American Type Culture Collection (ATCC) (Rockville, MD) strain 8722 of $P$. syringae pv. apii. Plants were kept in a greenhouse at $25^{\circ} \mathrm{C}$ and 70 to $80 \%$ relative humidity (RH), and disease symptoms were evaluated after 7 to 10 days.

Detection of epiphytic $P$. syringae pv. apii populations on leaves of celery transplants and monitoring of disease incidence in transplant operations. Celery transplants in three commercial transplant operations where BLS had occurred were monitored from 1991 through 1993. At monthly intervals from January through July, 50 asymptomatic leaves were collected arbitrarily along the entire length of transplant blocks at each operation. A transplant block consisted of one cultivar of equal age, and each greenhouse usually held one or two blocks. To assay for epiphytic bacteria, $\sim 10 \mathrm{~g}$ of leaves ( $\leq 50$ leaves) was sonicated (Ultrasonic FS-28, Fisher Scientific Co., Pittsburgh) for $20 \mathrm{~min}$ in 250-ml flasks containing $100 \mathrm{ml}$ of $0.1 \mathrm{M}$ potassium phosphate buffer ( $\mathrm{PB}, \mathrm{pH}$ 7.0). The liquid was strained through two layers of cheesecloth, and bacteria were collected by centrifugation at $10,000 \times g$ for $10 \mathrm{~min}$. The pellet was resuspended in $2 \mathrm{ml}$ of $\mathrm{PB}$ and serially diluted in 10-fold steps with PB. From each dilution, $100 \mu \mathrm{l}$ of suspension was spread on KB or modified KB (KBC), a semiselective medium for $P$. syringae pv. syringae (21). KBC was used in assays of epiphytic $P$. syringae pv. apii because it suppressed the growth of saprophytic bacteria that interfered with identification of $P$. syr- 
ingae pv. apii colonies on $\mathrm{KB}$, which allowed quantification of $P$. syringae pv. apii colonies from lower dilutions $\left(10^{0}\right.$ and $\left.10^{1}\right)$ of the wash buffer. Fluorescent colonies resembling those of $P$. syringae pv. apii were counted after 3 days at $28^{\circ} \mathrm{C}$, and representatives of these colonies were tested for oxidase and arginine dihydrolase activity and pathogenicity on celery leaves. $P$. syringae pv. apii populations on symptomless leaves were expressed as CFU per gram fresh weight.

Cultural practices and environmental conditions were monitored, and the time at which the first symptoms were apparent was recorded for each greenhouse surveyed. Leaves with symptoms were collected, and isolations were made as described above to confirm the presence of $P$. syringae pv. apii.

Sources of inoculum. Shoreflies (Ephydra riparia), which commonly are found in transplant greenhouses, were vacuumed from celery transplants with and without disease symptoms to determine whether these insects were contaminated with $P$. syringae pv. apii. Flies were collected from 15 celery transplant greenhouses over a 2-year period (1991 to 1992). Seven of the collections were from greenhouses with infected celery. A group of 50 shoreflies arbitrarily selected from each collection was sonicated in $10 \mathrm{ml}$ of PB for $20 \mathrm{~min}$, and $200 \mu \mathrm{l}$ of the undiluted liquid and a 1:10 dilution of the liquid in PB were plated on KBC. $P$. syringae pv. apii colonies were enumerated and identified as previously described.

Twenty-four seed lots provided by transplant growers and seed companies were tested for seedborne $P$. syringae pv. apii contamination. Three subsamples of $\sim 40,000$ seeds ( 20 to $24 \mathrm{~g}$ ) each were assayed from each lot. Subsamples were washed in $100 \mathrm{ml}$ of cold PB containing $20 \mu \mathrm{l}$ of Tween 20 (Fisher) in a $250-\mathrm{ml}$ flask on a shaker at $200 \mathrm{rpm}$ for $4 \mathrm{~h}$ at $4^{\circ} \mathrm{C}$. Bacteria in the wash liquid were collected as described for epiphytic bacteria. $P$. syringae pv. apii colonies on three plates of KBC and one plate of $\mathrm{KB}$ were enumerated and identified as previously described.

Production of $P$. syringae pv. apii-contaminated celery seed. In 1991, symptomless greenhouse-produced celery transplants (Gurza Special, West Coast Nurseries, Oxnard, CA) were transplanted into $15 \times 1-\mathrm{m}$ beds in a field at Hartnell College, Salinas, CA. Twelve weeks after transplanting, while plants were in the vegetative growth stage, all plants in a bed were spray-inoculated uniformly with 1 liter of a suspension containing $5 \times 10^{8} \mathrm{CFU}$ of $P$. syringae pv. apii strain 90029 per $\mathrm{ml}$ in nutrient broth. The suspension contained $4 \mathrm{~g}$ of Carborundum per liter and was delivered with a $\mathrm{CO}_{2}$ powered backpack sprayer set at $0.4 \mathrm{MPa}$. Noninoculated control plants were not sprayed. Beds with inoculated or noninoculated plants were arranged in a completely randomized design with three replicates of each, and replicates were separated by beds
Table 1. Epiphytic populations of Pseudomonas syringae pv. apii (Psa) on celery transplant leaves collected at three Salinas Valley transplant operations from 1991 to 1993

\begin{tabular}{|c|c|c|c|c|c|c|}
\hline \multirow[b]{2}{*}{$\begin{array}{l}\text { Year } \\
\quad \text { Month }\end{array}$} & \multicolumn{2}{|c|}{ Site 1} & \multicolumn{2}{|c|}{ Site 2} & \multicolumn{2}{|c|}{ Site 3} \\
\hline & $\begin{array}{c}\text { Plant age } \\
\text { (days) }^{w}\end{array}$ & $\begin{array}{l}\text { Psa pop. }^{\mathbf{x}} \\
\text { (log CFU) }\end{array}$ & $\begin{array}{c}\text { Plant age } \\
\text { (days) }\end{array}$ & $\begin{array}{c}\text { Psa pop. } \\
\text { (log CFU) }\end{array}$ & $\begin{array}{c}\text { Plant age } \\
\text { (days) }\end{array}$ & $\begin{array}{l}\text { Psa pop. } \\
\text { (log CFU) }\end{array}$ \\
\hline \multicolumn{7}{|l|}{1991} \\
\hline January & $28-35$ & 0 & 61 & 0 & $68-74$ & 0 \\
\hline February & $47-48$ & 0 & 62 & 0 & 64 & 0 \\
\hline March & $35-57$ & 0 & 69 & 0 & 71 & 0 \\
\hline April & $\begin{array}{l}35 \\
36 \\
42\end{array}$ & $\begin{array}{l}7.2 \\
0 \\
6.0\end{array}$ & 48 & 0 & $\begin{array}{l}41 \\
47\end{array}$ & $\begin{array}{l}0 \\
5.3^{* y}\end{array}$ \\
\hline May & $\begin{array}{l}26 \\
43 \\
51 \\
51\end{array}$ & $\begin{array}{l}0 \\
5.6 \\
8.7^{*} \\
7.2^{*}\end{array}$ & $\begin{array}{l}47 \\
48\end{array}$ & $\begin{array}{l}0 \\
6.7 *\end{array}$ & $\begin{array}{l}34 \\
36 \\
56\end{array}$ & $\begin{array}{l}7.3^{*} \\
0 \\
7.2^{*}\end{array}$ \\
\hline June & $\begin{array}{l}29 \\
29 \\
36 \\
42 \\
42\end{array}$ & $\begin{array}{l}0 \\
0 \\
6.3 \\
8.9^{*} \\
8.1^{*}\end{array}$ & $\begin{array}{l}35 \\
47 \\
70\end{array}$ & $\begin{array}{l}0 \\
0 \\
6.0^{*}\end{array}$ & 41 & 0 \\
\hline July & $\begin{array}{l}64 \\
68\end{array}$ & $\begin{array}{l}7.7^{*} \\
6.6^{*}\end{array}$ & & & & \\
\hline
\end{tabular}

1992

\begin{tabular}{|c|c|c|c|c|c|c|}
\hline January & & $\mathrm{ND}^{\mathrm{z}}$ & & ND & & ND \\
\hline February & $40-46$ & 0 & & ND & $41-49$ & 0 \\
\hline March & $36-71$ & 0 & $41-54$ & 0 & $47-66$ & 0 \\
\hline April & $\begin{array}{l}45 \\
51 \\
59\end{array}$ & $\begin{array}{l}0 \\
0 \\
0\end{array}$ & $\begin{array}{l}35 \\
70 \\
78\end{array}$ & $\begin{array}{l}0 \\
0 \\
5.7 *\end{array}$ & $\begin{array}{l}38 \\
53\end{array}$ & $\begin{array}{l}0 \\
0\end{array}$ \\
\hline May & $\begin{array}{l}21 \\
41 \\
41 \\
61\end{array}$ & $\begin{array}{l}0 \\
4.8^{*} \\
7.1^{*} \\
5.5^{*}\end{array}$ & $\begin{array}{l}32 \\
42 \\
42\end{array}$ & $\begin{array}{l}0 \\
0 \\
5.6^{*}\end{array}$ & $\begin{array}{l}34 \\
46 \\
54\end{array}$ & $\begin{array}{l}5.4 \\
6.5 \\
0\end{array}$ \\
\hline June & $\begin{array}{l}28 \\
41 \\
42 \\
49\end{array}$ & $\begin{array}{l}0 \\
0 \\
3.6 \\
0\end{array}$ & $\begin{array}{l}56 \\
60 \\
68\end{array}$ & $\begin{array}{l}0 \\
5.4^{*} \\
6.3^{*}\end{array}$ & $\begin{array}{l}37 \\
39 \\
48\end{array}$ & $\begin{array}{l}5.3^{*} \\
6.2^{*} \\
7.0^{*}\end{array}$ \\
\hline July & $\begin{array}{l}44 \\
59\end{array}$ & $\begin{array}{l}6.4^{*} \\
7.0^{*}\end{array}$ & $\begin{array}{l}48 \\
52 \\
70\end{array}$ & $\begin{array}{l}5.7^{*} \\
3.2 \\
6.1^{*}\end{array}$ & $\begin{array}{l}38 \\
43\end{array}$ & $\begin{array}{l}4.6^{*} \\
6.3^{*}\end{array}$ \\
\hline
\end{tabular}

1993

\begin{tabular}{lclclcl} 
January & & ND & & ND & ND \\
February & $35-58$ & 0 & $58-65$ & 0 & $50-55$ & 0 \\
March & $35-70$ & 0 & $48-72$ & 0 & $45-58$ & 0 \\
April & 34 & 2.4 & 35 & 0 & 54 & 0 \\
& 53 & $7.3^{*}$ & 36 & 0 & & \\
& 61 & 4.9 & 42 & 0 & & \\
May & 28 & 0 & 64 & 4.0 & & \\
& 42 & 5.7 & 41 & 0 & & \\
& 46 & $4.9^{*}$ & 54 & 0 & & \\
June & 61 & 4.7 & 54 & 0 & & \\
& 27 & 0 & 28 & 0 & 31 & \\
& 28 & 0 & 43 & 0 & 41 & \\
July & 35 & $7.2^{*}$ & 54 & 0 & & \\
& 29 & 0 & 31 & 0 & & \\
& 42 & 0 & 39 & 0 & & \\
& 46 & $3.0^{*}$ & 45 & 0 & & \\
\hline
\end{tabular}

${ }^{\mathrm{w}}$ Days after seeding.

${ }^{x}$ Log CFU/g fresh weight determined from leaf-wash assays on semiselective medium. Numbers represent mean counts from three plates per sample. Each sample consisted of 50 leaves arbitrarily collected from different celery plants in a single transplant block containing one cultivar.

${ }^{y}$ Bacterial leaf spot symptoms observed on transplants in the greenhouse from which leaves were collected.

${ }^{\mathrm{z}}$ No samples collected. 
of untreated celery. The field was irrigated with overhead sprinklers. Visual assessments of disease began 4 weeks after inoculation. Infected plants were assayed as previously described to confirm the presence of the pathogen.

Seed from inoculated and noninoculated plants was harvested 8 months after transplanting. The seeds were dried and stored in cloth bags at room temperature. Harvested seed was sifted to remove immature seeds and debris, and a 4.9-g ( 10,000 seeds) subsample from each inoculated bed was assayed for $P$. syringae pv. apii as previously described. Seed from inoculated plants was combined and designated as HC-I.

At harvest, 10 green and 10 dry umbels from each replicate also were assayed for $P$. syringae pv. apii. Umbels were shredded, and 4-g subsamples of green or dry tissue were sonicated in $150 \mathrm{ml}$ of $\mathrm{PB}$ for $20 \mathrm{~min}$. Tenfold serial dilutions were prepared in $\mathrm{PB}$, and $100 \mu \mathrm{l}$ from $10^{-2}$ and $10^{-3}$ dilutions was spread on plates of KBC. P. syringae pv. apii colonies were identified as before.

Transmission of $P$. syringae pv. apii from seed to seedlings. Seeds from HC-I and a commercially produced seed lot (cv. Conquistador) that had no detectable $P$. syringae pv. apii contamination (based on the seed-wash assay) each were densely seeded into a single $35 \times 50-\mathrm{cm}$ metal planting tray filled with University of California greenhouse potting mixture (UC mix). The trays were well separated in a greenhouse at $26^{\circ} \mathrm{C}$ and 70 to $80 \% \mathrm{RH}$ and were sprinkled daily to provide leaf wetness. Fifty leaves were collected from plants in each tray every 2 weeks, beginning 4 weeks after emergence. The composite of 50 leaves was assayed for $P$. syringae pv. apii as described previously.

Effects of seed treatments on seedborne $P$. syringae pv. apii and seed germination. In the first series of experiments, 100-g samples of HC-I seed were (i) soaked for $25 \mathrm{~min}$ in a $50^{\circ} \mathrm{C}$ water bath; (ii) soaked for $25 \mathrm{~min}$ in $0.26 \% \mathrm{NaOCl}$ (5\% household bleach) at room temperature; (iii) soaked for $25 \mathrm{~min}$ in $0.03 \%$ $\mathrm{NaOCl}\left(0.5 \%\right.$ household bleach) at $35^{\circ} \mathrm{C}$; or (iv) not treated. The wash water was agitated during the treatments. Three subsamples of $\sim 40,000$ seeds from each treatment were assayed for $P$. syringae pv. apii with the seed assay. Percent germination for each treatment was determined from 3 sets of 100 seeds each. Each set was planted in a $15-\mathrm{cm}$ pot containing UC mix and maintained under cool-white fluorescent lights $\left(12 \mathrm{~h} /\right.$ day) at $24^{\circ} \mathrm{C}$ for 21 days, at which time seedlings were counted. Germination of hot-water treated $\left(50^{\circ} \mathrm{C}\right.$ for $\left.25 \mathrm{~min}\right)$ and nontreated seed was determined again 16 months later. The experiment was repeated three times.

In a second series of experiments, conducted 2 years after harvest of the seed, 100-g samples of HC-I seed were immersed and agitated in hot water at (i) $50^{\circ} \mathrm{C}$ for 25 min; (ii) $50^{\circ} \mathrm{C}$ for $50 \mathrm{~min}$; (iii) $55^{\circ} \mathrm{C}$ for 25 min; (iv) $55^{\circ} \mathrm{C}$ for $50 \mathrm{~min}$; (v) $60^{\circ} \mathrm{C}$ for 25 min; or (vi) $60^{\circ} \mathrm{C}$ for $50 \mathrm{~min}$. Controls were untreated. Seeds were assayed for $P$. syringae pv. apii as in the first series of experiments, and percent seed germination was determined on blotter paper (7). Each of three subsamples of 100 seeds from each treatment was spread on two layers of Whatman (Hillsboro, OR) No. 1 filter paper in a glass petri plate. The paper was wetted with sterile water, and $1 \mathrm{ml}$ of $0.2 \%$ thiram solution was added to prevent fungal growth. Plates were incubated at $24^{\circ} \mathrm{C}$ under cool-white fluorescent light for $8 \mathrm{~h} /$ day. Germinated seeds were counted 14 and 21 days after plating. The experiment was repeated three times.

Data on seedborne $P$. syringae pv. apii and seed germination were compared by Tukey's mean comparisons after analysis of variance (PROC ANOVA, SAS Institute, Cary, NC) for a randomized completeblock design; the three repeats were considered blocks in the analysis, and data from the three subsamples for the $P$. syringae pv. apii and seed germination assays were averaged for each treatment.

\section{RESULTS}

Identification of the causal agent of BLS of celery in California. A fluorescent pseudomonad was isolated consistently from celery leaves with BLS symptoms. The 35 strains of this bacterium subjected to LOPAT tests were negative for cytochrome oxidase, arginine dihydrolase, and ability to rot potatoes and positive for production of levan from sucrose and induction of hypersensitive reaction in tobacco. The ATCC strain of $P$. syringae pv. apii produced identical reactions. These results indicate that the fluorescent bacterium associated with BLS in California is $P$. syringae. Of the 73 bacterial strains isolated from diseased celery leaves, only the $P$. syringae strains produced small water-soaked spots that turned dark brown, necrotic, and eventually coalesced. These symptoms were identical to those from inoculation with the ATCC strain. Controls did not develop symptoms.

Epiphytic $P$. syringae pv. apii and disease incidence in transplant operations. Epiphytic $P$. syringae pv. apii was detected on celery in 43 of 140 samples from celery transplant blocks. For 30 of the 43 positive samples, some plants in the block had obvious BLS symptoms. For the other 13 positive samples, no plants had apparent symptoms at the time of sampling, but BLS developed within 10 days after sampling. Neither $P$. syringae pv. apii nor BLS symptoms were detected before April or May of each year (Table 1), 3 to 4 months after the transplant season began during January. $P$. syringae pv. apii populations on celery transplant leaves ranged from $10^{2}$ to $10^{7} \mathrm{CFU} / \mathrm{g}$ of leaf tissue when none of the plants in the block showed symptoms. When some plants in the block had BLS, bacterial populations ranged from $10^{3}$ to $10^{9}$ $\mathrm{CFU} / \mathrm{g}$. After BLS was apparent, large populations of $P$. syringae $\mathrm{pv}$. apii on leaves and BLS symptoms generally persisted until the transplants were moved out of the greenhouse. After initial BLS outbreaks occurred in a transplant operation, the disease persisted in transplant greenhouses throughout the transplant season (July or August).

Sources of inoculum. $P$. syringae pv. apii ( $\sim 10^{5}$ CFU/50 flies) was detected in two of seven collections of shoreflies from greenhouses with symptomatic transplants. $P$. syringae pv. apii was not detected in insect collections from houses where disease incidence was low nor from houses with apparently healthy transplants. P. syringae pv. apii-contaminated shoreflies were collected during May and June, when BLS pressure was high in all transplant operations (Table 1).

P. syringae pv. apii was recovered from 5 of 24 commercial celery seed lots. Contamination of the commercial lots ranged from 10 to $91 \mathrm{CFU} / \mathrm{g}$ of seed $(1 \mathrm{~g}=2,000$ seeds). $P$. syringae $\mathrm{pv}$. apii colonies were apparent on semiselective $\mathrm{KBC}$, but plates of $\mathrm{KB}$ were often overgrown with saprophytic bacteria and fungi.

Production of contaminated seed. In field tests, epiphytic $P$. syringae pv. apii populations were detected readily on flower umbels and seeds of celery plants inoculated with $P$. syringae pv. apii at the vegetative growth stage. $P$. syringae pv. apii was isolated consistently from lesions on leaves and flower sepals of inoculated plants, although very few lesions were observed on inoculated plants. Populations on umbels ranged from $10^{5}$ to $10^{6}$ and from 0 to $10^{5} \mathrm{CFU} / \mathrm{g}$ of fresh tissue for inoculated and noninoculated plants, respectively. Seed (HC-I) collected from inoculated plants was heavily contaminated $\left(2 \times 10^{5} \mathrm{CFU} / \mathrm{g}\right)$.

Regular assays of plants grown from infected seed showed $P$. syringae pv. apii populations of $3.6 \times 10^{1} \mathrm{CFU} / \mathrm{g}$ fresh leaf weight by 6 weeks and increased populations of $1 \times 10^{5} \mathrm{CFU} / \mathrm{g}$ by 8 weeks. Populations remained at $10^{4}$ to $10^{5} \mathrm{CFU} / \mathrm{g}$ fresh leaf weight throughout the 12 weeks of the experiment, but BLS symptoms did not develop on leaves of these seedlings. $P$. syringae pv. apii was not recovered from leaves of control seedlings.

Evaluation of seed treatments for eradication of $P$. syringae pv. apii from seed and effects on seed germination. Hot water $\left(50^{\circ} \mathrm{C}\right.$ for $\left.25 \mathrm{~min}\right)$ eliminated $>99.9 \%$ of the $P$. syringae pv. apii from HC-I seed in the first series of experiments (Table 2). $\mathrm{NaOCl}$ treatments were less effective, although $0.26 \% \mathrm{NaOCl}$ reduced $P$. syringae pv. apii contamination $96 \%$ compared to nontreated controls. Germination was not reduced significantly by any of the treatments in the first series of experiments. In the second experiment, soaking HC-I seed 
in water at $50^{\circ} \mathrm{C}$ for $25 \mathrm{~min}$ eliminated $>99.9 \%$ of the pathogen but also significantly $(P=0.0001)$ reduced seed germination (Table 3 ). Treatments with higher temperatures or extended treatment times completely eliminated $P$. syringae pv. apii from seed but reduced germination considerably (Table 3 ).

\section{DISCUSSION}

The sudden appearance and rapid spread of BLS in California suggests the pathogen was introduced recently. Assays of diseased plants and characterization of the pathogen have shown BLS is induced by $P$. syringae pv. apii, which also causes BLS of celery in the Midwestern and Eastern regions of the United States $(8,10,11,24)$, rather than by $P$. cichorii, which causes bacterial blight of celery in Florida $(26,27)$. In additional studies in our laboratory, $P$. syringae pv. apii strains from diseased celery in California were closely related to the $P$. syringae pv. apii type strain and to P. syringae pv. apii strains from Michigan by restriction fragment length polymorphism and random amplified polymorphic DNA analyses and by cross-pathogenicity tests involving other $P$. syringae pathovars and plant species (16).

Epiphytic development of bacterial pathogens may be an important precursor to disease (6), but $P$. syringae pv. apii was not detected on transplants in commercial greenhouses for 3 to 4 months after the beginning of the transplant season. The apparent lag may represent undetectable levels of initial inoculum $(12,14,25)$, relatively small sample sizes, or the detection limit of the assay procedure. For example, plating efficiency comparisons showed recovery of $P$. syringae pv. apii on $\mathrm{KBC}$ was reduced as much as $80 \%$ compared to recovery on KB (data not shown). The presence of large bacterial populations on transplants 1 month after nondetection indicated rapid population increases. The high humidity and moisture conditions found in transplant greenhouses are likely to favor infections developing from seed lots with low levels of contamination $(4,12,13,20,23)$.

Recovery of $P$. syringae pv. apii from commercial celery seed indicates that the pathogen can be seedborne and supports the hypothesis that $P$. syringae pv. apii was introduced into California celery production via contaminated seed, but the nature of the seed association is unknown. Surfacesterilization of seed with sodium hypochlorite did not eliminate the pathogen, indicating the pathogen may colonize indentations and openings in the seed coat that are resistant to wetting. Poor recovery of the pathogen from shoreflies indicates that secondary spread of the pathogen by this prevalent insect is probably minor. The pathogen was detected on seedlings grown from contaminated celery seed, which establishes an important epidemiological link to the inoculum source. The rate of seed contamination was not determined; however, relatively few bacteria detected in commercial seed and nondetection during early season transplant assays indicate infrequent contamination.

Celery seed infection was found in a field trial in which seed from inoculated plants was heavily contaminated with $P$. syringae pv. apii. The pathogen was detected readily on inoculated plants but also was found on nearby noninoculated plants. Few inoculated plants and no control plants developed BLS symptoms, which suggests that visual inspection of celery seed fields for BLS may not be sufficient to preclude seed contamination.

The most effective seed treatment to eliminate seed contamination was a water soak at $50^{\circ} \mathrm{C}$ for $25 \mathrm{~min}$. This treatment substantially reduced the number of seedborne bacteria in a heavily contaminated seed lot and would be practical for commercial lots. Equally important, this treatment did not reduce germination of seed, which was tested immediately after treatment and again 16 months later. However, when seed was stored for 2 years prior to the second seed treatment experiment, a slight but significant reduction in seed germination was observed after treatment at $50^{\circ} \mathrm{C}$ for $25 \mathrm{~min}$. The storage period may have increased the sensitivity of the seed embryo to injury from the hot water. In- creased sensitivity of seed stored for several years compared to newly harvested seed has been reported previously for celery and crucifer seeds $(1,28)$. Therefore, growers must weigh the benefits of hot-water treatment for eradication of $P$. syringae pv. apii from celery seed with the possible negative effects of reduced seed germination, especially if the seed has been stored or if the time and temperature of the seed treatment cannot be controlled precisely.

BLS was found in transplant seedlings from seed in which $P$. syringae pv. apii was not found by the seed-wash assay. Either these seeds were contaminated at levels below the detection limit of the assay, or the inoculum was from another unknown source. There is no established tolerance level for $P$. syringae pv. apii contamination of celery seed, but such a threshold would be low or zero tolerance given the rapid rate at which the disease can develop in transplant greenhouses. Therefore, effective management of BLS will likely involve the routine use of hot water-treated seed.

Several environmental and cultural practices were associated with increased $P$. syringae pv. apii populations. In almost all greenhouses, transplants were overhead spray irrigated once or twice a day with water at 0.3 to $0.4 \mathrm{MPa}$, dispersed through flat-fan spray nozzles positioned $\sim 15$ to $30 \mathrm{~cm}$ above the plants. Water-soaked leaves were

Table 2. Effects of hot water and sodium hypochlorite on seed germination and number of Pseudomonas syringae pv. apii (Psa) in contaminated celery seed

\begin{tabular}{|c|c|c|c|c|}
\hline Treatment & $\begin{array}{c}\text { Psa recovered } \\
\text { from seed }^{v} \\
\text { (log CFU/g seed) }\end{array}$ & $\begin{array}{c}\text { Reduction in Psa } \\
\text { contamination }^{\mathrm{w}} \\
(\%)\end{array}$ & $\underset{(\%)}{\text { Germination }^{\mathrm{x}}}$ & $\begin{array}{c}\text { Germination } \\
\text { after } 16 \text { months } \\
(\%)\end{array}$ \\
\hline None & $3.4 \mathrm{a}^{\mathrm{y}} \pm 2.9$ & 0 & $73 \mathrm{a}$ & $67 \mathrm{a}$ \\
\hline $\begin{array}{l}50^{\circ} \mathrm{C} \mathrm{H}_{2} \mathrm{O}, 25 \mathrm{~min} \\
0.26 \% \mathrm{NaOCl},\end{array}$ & $-1.0 \mathrm{c} \pm-0.7$ & $>99$ & $76 \mathrm{a}$ & $77 \mathrm{a}$ \\
\hline $\begin{array}{l}23^{\circ} \mathrm{C}, 25 \mathrm{~min} \\
0.03 \% \mathrm{NaOCl}\end{array}$ & $2.0 \mathrm{~b} \pm 1.9$ & 96 & $75 \mathrm{a}$ & $\mathrm{ND}^{\mathrm{z}}$ \\
\hline $35^{\circ} \mathrm{C}, 25 \mathrm{~min}$ & $2.9 \mathrm{a} \pm 2.3$ & 69 & $66 \mathrm{a}$ & ND \\
\hline
\end{tabular}

${ }^{v}$ Mean \pm standard error of bacterial counts from three replicates for each treatment. Each replicate is the mean of three seed subsample assays.

${ }^{\text {w}}$ Percent reduction relative to number of bacteria recovered from untreated seed $(\log 3.4 \mathrm{CFU} / \mathrm{g}$ of seed)

${ }^{x}$ Based on 300 seeds per replicate.

${ }^{y}$ Values followed by the same letter are not significantly different at $P=0.05$, based on Tukey's mean comparisons after analysis of variance.

${ }^{z}$ Not determined.

Table 3. Effects of temperature and duration of hot-water treatments on seed germination and number of Pseudomonas syringae pv. apii (Psa) in contaminated celery seed

\begin{tabular}{|c|c|c|c|}
\hline Treatment & $\begin{array}{l}\text { Psa recovered from seed } \\
(\log \text { CFU/g seed })\end{array}$ & $\begin{array}{l}\text { Reduction in Psa } \\
\text { contamination }(\%)\end{array}$ & Germination $^{\mathrm{z}}(\%)$ \\
\hline None & $2.0 \pm 2.2$ & 0 & $81 \mathrm{a}$ \\
\hline $50^{\circ} \mathrm{C}, 25 \mathrm{~min}$ & $-0.7 \pm-0.2$ & $>99$ & $69 \mathrm{~b}$ \\
\hline $50^{\circ} \mathrm{C}, 50 \mathrm{~min}$ & 0 & 100 & $46 c$ \\
\hline $55^{\circ} \mathrm{C}, 25 \mathrm{~min}$ & 0 & 100 & $10 \mathrm{~d}$ \\
\hline $55^{\circ} \mathrm{C}, 50 \mathrm{~min}$ & 0 & 100 & 0 \\
\hline $60^{\circ} \mathrm{C}, 25 \mathrm{~min}$ & 0 & 100 & 0 \\
\hline $60^{\circ} \mathrm{C}, 55 \mathrm{~min}$ & 0 & 100 & 0 \\
\hline
\end{tabular}

${ }^{\mathrm{x}}$ Mean \pm standard error of bacterial counts in three replicates. Each replicate is the mean of three seed subsample assays.

y Percent reduction relative to number of bacteria recovered from untreated seed.

${ }^{z}$ Based on germination assays, 300 seeds per test. Values followed by the same letter are not significantly different at $P=0.05$, based on Tukey's mean comparisons after analysis of variance. 
common after irrigation. In houses that eventually had celery with BLS, watersoaked areas often developed into brown necrotic lesions from which $P$. syringae pv. apii was isolated readily. Apparently, irrigation-induced water soaking is an effective mechanism for $P$. syringae pv. apii infiltration into leaves. Irrigation-induced water soaking and severe BLS symptoms were more frequent later in the growing season (May to July), when celery grew rapidly and leaves were succulent. In 1993, celery transplant growers who reduced the pressure of the irrigation spray produced transplants with little or no irrigationinduced water soaking or BLS. Similarly, growers who reduced nitrogen applications in 1993 produced transplants with smaller, thicker, less succulent leaves. Epidemiologically, $P$. syringae pv. apii seems similar to $P$. syringae pv. tabaci on tobacco, in which high levels of nitrogen fertilizer increased leaf susceptibility to water soaking during rain, which resulted in increased disease (3).

In greenhouses, 6- to 7-week-old transplants commonly are trimmed with rotary mowers suspended from overhead booms to promote vigorous and uniform growth. Sometimes a second mowing is necessary. Mowing wounds transplants and distributes leaf debris throughout the greenhouse. Secondary spread of $P$. syringae pv. apii in greenhouses probably occurred during mowing $(2,5,19)$. BLS generally was observed after the first mowing, but some younger transplants with only the first true leaves showed symptoms and had epiphytic populations of $P$. syringae pv. apii, especially when disease pressure was high. Mowing is considered essential for production of the uniform celery transplants needed for field planting. Growers who applied copper compounds (e.g., Kocide DF) after the first mowing observed no apparent control. The simple expedient of mowing transplants when the leaves are dry may reduce dissemination (22). Because shoreflies also may disperse inoculum within and between houses, some growers have initiated shorefly control programs.

Based on our study, the experience of growers, and adaptations from similar disease management programs, several BLS management techniques are proposed. Celery seed should be treated with hot water $\left(50^{\circ} \mathrm{C}\right.$ for $\left.25 \mathrm{~min}\right)$ to reduce initial inoculum. Planting trays and greenhouses should be disinfested between celery transplant seasons. The pressure of spray-irrigation water should be reduced to avoid irrigation-induced water soaking of leaves. Plants should be irrigated on a schedule that will minimize duration of leaf wetness. Exces- sive application of fertilizers, especially those high in nitrogen, should be avoided. Mowers should be cleaned and disinfested between greenhouses. Mowing should be done only when plants are dry. Movement of workers between greenhouses, particularly when BLS is present and plants are wet, should be restricted. Worker sanitation (disinfesting hands and changing clothes) should be practiced, especially between greenhouses. Employment of some or all of these techniques by transplant growers already has reduced BLS incidence and severity in Salinas Valley transplant greenhouses.

\section{ACKNOWLEDGMENTS}

This work was partially supported by a grant from the California Celery Research Board and by the College of Agricultural and Environmental Sciences, University of California-Davis. E. L. Little was supported in part by a Jastro Shields Graduate Research Scholarship and by a fellowship from the College of Agriculture and Environmental Sciences, University of California-Davis. We thank celery transplant growers in the Salinas Valley of California for their cooperation throughout this study and R. McCoy and A. Greathead for insightful discussions and encouragement.

\section{LITERATURE CITED}

1. Bant, J. H., and Storey, I. F. 1952. Hot-water treatment of celery seed in Lancashire. Plant Pathol. 1:81-83.

2. Chang, R. J., Ries, S. M., and Pataky, J. K. 1991. Dissemination of Clavibacter michiganensis subsp. michiganensis by practices used to produce tomato transplants. Phytopathology 81:1276-1281.

3. Clayton, E. E. 1936. Water soaking of leaves in relation to development of the wildfire disease of tobacco. J. Agric. Res. 52:239-269.

4. Fryda, S. J., and Otta, J. D. 1978. Epiphytic movement and survival of Pseudomonas syringae on spring wheat. Phytopathology 68: 1064-1067.

5. Gitaitis, R., McCarter, S., and Jones, J. 1992. Disease control in tomato transplants produced in Georgia and Florida. Plant Dis. 76: 651-656.

6. Hirano, S. S., and Upper, C. D. 1990. Population biology and epidemiology of Pseudomonas syringae. Annu. Rev. Phytopathol. 28: 155-177.

7. International Seed Testing Association. 1985. International rules for seed testing. Seed Sci. Technol. 13:299-355.

8. Jagger, I. C. 1921. Bacterial leaf spot disease of celery. J. Agric. Res. 21:185-188.

9. King, E. O., Ward, M. K., and Raney, D. E. 1954. Two simple media for the demonstration of pyocyanin and fluorescein. J. Lab. Clin. Med. 44:301-307.

10. Koike, S. T., and Bishop, A. L. 1990. Bacterial leaf spot of celery caused by Pseudomonas syringae pv. apii in California. (Abstr.) Phytopathology 80:890.

11. Koike, S. T., Little, E. L., Bishop, A. L., and Gilbertson, R. L. 1994. New celery disease appears in California. Calif. Agric. 48:32-34.

12. Leben, C. 1963. Multiplication of Xanthomonas vesicatoria on tomato seedlings. Phytopathology 53:778-781.
13. Leben, C., and Daft, G. C. 1966. Migration of bacteria on seedling plants. Can. J. Microbiol. 12:1119-1123.

14. Leben, C., Schroth, M. N., and Hildebrand, D. C. 1970. Colonization and movement of Pseudomonas syringae on healthy bean seedlings. Phytopathology 60:677-680.

15. Lelliot, R. A., Billing, E., and Hayward, A. C. 1966. A determinative scheme for the fluorescent plant pathogenic pseudomonads. J. Appl. Bacteriol. 29:470-489.

16. Little, E. L., and Gilbertson, R. L. Phenotypic and genotypic characters support placement of Pseudomonas syringae strains from tomato, celery, and cauliflower into distinct pathovars. In: Pseudomonas syringae Pathovars and Related Pathogens. K. Rudolph, T. J. Burr, J. W. Mansfield, D. Stead, A. Vivian, and J. von Kietzell, eds Kluwer Academic Publishers, Dordrecht, Netherlands. In press.

17. Little, E. L., Koike, S. T., and Gilbertson, R. L. 1991. Celery bacterial blight: A new and increasingly important disease in California. Pages 223-226 in: Proc. 4th Int. Working Group Pseudomonas syringae Pathovars. Stampería Granducale, Firenze, Florence, Italy.

18. Little, E. L., Koike, S. T., and Gilbertson, R. L. 1992. Association of Pseudomonas syringae pv. apii with celery seed. (Abstr.) Phytopathology 82:1072.

19. McCarter, S. M., and Jaworski, C. A. 1969. Field studies on spread of Pseudomonas solanacearum and tobacco mosaic virus in tomato plants by clipping. Plant Dis. Rep. 53: 942-946.

20. McCarter, S. M., Jones, J. B., Gitaitis, R. D., and Smitley, D. R. 1983. Survival of Pseudomonas syringae pv. tomato in association with tomato seed, soil, host tissue, and epiphytic weed hosts in Georgia. Phytopathology 73: 1393-1398.

21. Mohan, S. K., and Schaad, N. W. 1987. An improved agar plating assay for detecting Pseudomonas syringae pv. syringae and $P$. $s$. pv. phaseolicola in contaminated bean seed. Phytopathology 77:1390-1395.

22. Pohronezny, K., Moss, M. A., Dankers, W., and Schenk, J. 1990. Dispersal and management of Xanthomonas campestris pv. vesicatoria during thinning of direct-seeded tomatoes. Plant Dis. 74:800-805.

23. Roberts, S. J. 1992. Effect of soil moisture on the transmission of pea bacterial blight (Pseudomonas syringae pv. pisi) from seed to seedling. Plant Pathol. 41:136-140.

24. Sherf, A. F., and Macnab, A. A., eds. 1986. Northern bacterial blight of celery. Pages 157158 in: Vegetable Diseases and Their Control. 2nd ed. John Wiley \& Sons, New York.

25. Smitley, D. R., and McCarter, S. M. 1982 Spread of Pseudomonas syringae pv. tomato and role of epiphytic populations and environmental conditions in disease development. Plant Dis. 66:713-717.

26. Thayer, P. L. 1965. Temperature effect on growth and pathogenicity to celery of Pseudomonas apii and P. cichorii. (Abstr.) Phytopathology 55:1365.

27. Thayer, P. L., and Wehlburg, C. 1965. Pseudomonas cichorii, the cause of bacterial blight of celery in the Everglades. Phytopathology 55:554-557.

28. Williams, P. H. 1980. Black rot: A continuing threat to world crucifers. Plant Dis. 64:736742. 